\title{
Population ecology of an alien "warm water" crayfish (Procambarus clarkii) in a new cold habitat
}

\author{
C. Chucholl ${ }^{(1,2)}$ \\ Received February 28, 2011 \\ Revised May 1, 2011 \\ Accepted May 30, 2011
}

Key-words: life-history plasticity, non-indigenous crayfish, latitudinal clines

\section{ABSTRACT}

Procambarus clarkii is one of the worst invasive and best-studied crayfish species worldwide, but its life history at higher latitudes is poorly understood. In the present study, the population ecology of $P$. clarkii was studied for the first time within its northeastern range limit in Europe (southern Germany) for a two-year period, and the findings are used to discuss several life-history parameters across different latitudes of its current distribution range. The reproductive cycle was tracked using the gonadosomatic index and reproductive traits in females and the reproductive form in males. Life-history parameters were estimated using Von Bertalanffy's growth function. Reproduction was univoltine and occurred from late summer to autumn. A small proportion of females carried eggs throughout the winter. This contrasts with the species' multi-voltine life cycle at lower latitudes, with year-round breeding and several reproduction peaks per year. Growth was estimated to be slower than at lower latitudes, whereas longevity, mean lifetime and size increased. These changes in life history probably reflect a general phenomenon at higher latitudes and, thus, latitudinal clines. The presented findings provide evidence that $P$. clarkii is able to cope well with new cold habitats by modulating its life history.

\section{RÉSUMÉ}

\section{Écologie des populations d'écrevisses non indigènes « d'eau chaude » (Procambarus clarkii) dans un nouvel habitat froid}

Mots-clés : plasticité d'histoire de vie, écrevisses, gradients latitudinaux
Procambarus clarkii est l'une des pires espèces d'écrevisses envahissantes et la mieux étudiée à travers le monde, mais son histoire de vie à des latitudes plus élevées est mal comprise. Dans la présente étude, l'écologie des populations de $P$. clarkii a été étudiée pour la première fois dans sa limite nord-est en Europe (sud de l'Allemagne) pour une période de deux ans, et les résultats sont utilisés pour examiner plusieurs paramètres d'histoire de vie aux différentes latitudes de son aire de répartition actuelle. Le cycle de reproduction a été suivi en utilisant l'indice gonadosomatique et les caractères de reproduction chez les femelles et la reproduction chez les mâles. Les paramètres d'histoire de vie ont été estimés en utilisant la fonction de croissance de Von Bertalanffy. La reproduction a été univoltine et a eu de la fin de l'été à l'automne. Une faible proportion de femelles porte des œufs tout au long de l'hiver. Cela contraste avec le cycle de l'espèce

(1) Dept. of Experimental Ecology (Bio 3), University of Ulm, Albert-Einstein-Allee 11, 89069 UIm, Germany, Cchucholl@aol.com

(2) Present adress: Fisheries Research Station BW, Lake Constance; Argenweg 50/1, 88085 Langenargen, Germany 
multi-voltine à des latitudes plus basses, avec des œufs portés toute l'année et plusieurs pics de reproduction par an. La croissance a été estimée à plus lente qu'aux basses latitudes, tandis que la longévité, durée de vie moyenne et la taille sont augmentées. Ces changements dans l'histoire de la vie sont probablement le reflet d'un phénomène général à des latitudes plus élevées et, par conséquent, des gradients latitudinaux. Les résultats présentés démontrent que $P$. clarkii est capable de bien s'adapter à de nouveaux habitats froids par la modulation de son histoire de vie.

\section{INTRODUCTION}

Invasive alien species (IAS) are an increasing, major threat to global biodiversity. This is especially true when IAS act as keystone species (Lodge et al., 2000; Sala et al., 2000; McGeoch et al., 2010). Crayfish are the largest mobile freshwater invertebrates and have been frequently recognised as key members of littoral food webs (Nyström, 1999, 2002). The red swamp crayfish, Procambarus clarkii (Girard, 1852), is the world's most invasive crayfish species and is listed among the "100 of the worst" IAS in Europe (DAISIE, 2010). Procambarus clarkii shows considerable ecological plasticity and is one of the most important freshwater decapods farmed for food consumption (Gutiérrez-Yurrita et al., 1999; Huner, 2002; Gherardi, 2006). The natural range of $P$. clarkii comprises the central south of the USA and northeastern Mexico. However, it is now established on every continent except Australia and Antarctica and has invaded even remote islands like the Azores, Canaries and Hawaii as a result of human-mediated translocation (Hobbs et al., 1989; Huner, 2002; Souty-Grosset et al., 2006). The red swamp crayfish was first imported into Europe in 1973 when Spain intentionally introduced the species for commercial crayfish production. Procambarus clarkii rapidly established self-sustaining populations and is now the most abundant crayfish species on the Iberian Peninsula. The first illegal introductions into France and Italy occurred soon after its introduction to Spain (Gutiérrez-Yurrita et al., 1999; Huner, 2002; Gherardi, 2006). Today, $P$. clarkii is widespread and abundant throughout southwestern Europe and northern and central Italy, whereas northeastern populations in the Netherlands, Belgium, Great Britain, Germany, Switzerland and Austria are mainly scattered and isolated from each other (cf. Figure 9). Procambarus clarkii has also become popular as an ornamental aquarium species, and many populations in Central Europe are the result of pet releases (Dehus et al., 1999; Soes and van Eekelen, 2006; Dümpelmann et al., 2009).

The red swamp crayfish is a polytrophic omnivore, and its ecological impact on native ecosystems can be devastating (Rodríguez et al., 2005; Gherardi, 2006; Souty-Grosset et al., 2006). Procambarus clarkii also poses a serious threat to the imperilled indigenous European crayfish, as it is a carrier of Aphanomyces astaci Schikora 1906, the causative agent of the crayfish plague. Aphanomyces astaci is a parasitic oomycete native to North America and fatal for all European crayfish. Further adverse impacts include damage to dams and dykes resulting from burrowing. Procambarus clarkii is especially considered a pest in agricultural areas, such as rice paddies, where it damages young rice plants as well as irrigation systems and dams (Gherardi, 2006; Souty-Grosset et al., 2006). Hobbs et al. (1989) reported that the majority of $P$. clarkii introductions have had negative consequences.

Although P. clarkii is often considered as a "warm water" species (Henttonen and Huner, 1999), it has also been found to thrive in colder climates at higher latitudes and altitudes in North America, Japan and Europe (Suko, 1958; Frutiger et al., 1999; Lindqvist and Huner, 1999; Müller, 2007; Dümpelmann et al., 2009; Chucholl, 2011). The life history of $P$. clarkii at warmer temperature regimes is well understood, and it is characterised by fast growth rates, early maturation, a short life-span and year-round breeding with reproduction peaks in the spring and the autumn in permanent habitats (Gherardi et al., 1999; Gutiérrez-Yurrita et al., 1999; Scalici and Gherardi, 2007). Individual egg-bearing females are present at any time during the year, which represents a unique life history trait and enhances this species' potential 
to become invasive (Lindqvist and Huner, 1999). However, there is an apparent lack of information on the life history of $P$. clarkii in colder environments, where low winter temperatures probably shorten the breeding season and restrict growth (cf. Frutiger et al., 1999).

The major motivation for the present study was to fill this gap in knowledge and to present life-history parameters and population dynamics of naturalised $P$. clarkii populations in southern Germany, which is within its northeastern range limit in Europe. Von Bertalanffy's growth function was used to estimate growth characteristics, longevity and mortality. The reproductive cycle was followed using the gonadosomatic index and reproductive traits in females, and the reproductive form in males. The findings are used to discuss several life-history parameters of $P$. clarkii across different latitudes of its current distribution range, thus providing a better understanding of its remarkable invasive success.

\section{METHODS}

\section{> STUDY SITES AND SAMPLING PERIOD}

To assess population dynamics and life-history parameters of $P$. clarkii, a population in Lake Riedheim (LR), a mesotrophic gravel pit lake (9.3 ha; $450 \mathrm{~m}$ above sea level; $48^{\circ} 27^{\prime} 32.4^{\prime \prime} \mathrm{N}$, $\left.10^{\circ} 10^{\prime} 32.3^{\prime \prime} \mathrm{E}\right)$, was sampled at least once per month from May 1 to October 2, 2007 and from April 16 to August 29, 2008. Furthermore, female reproductive traits were followed closely in Lake Burlafingen (LB; also a mesotrophic gravel pit lake. 5.1 ha; $456 \mathrm{~m}$ above sea level; $48^{\circ} 25^{\prime} 28.7^{\prime \prime} \mathrm{N}, 10^{\circ} 04^{\prime} 27.4^{\prime \prime}$ E) from September 12, 2008 through March 19, 2009. Both lakes are part of an artificial lake system along the River Danube in southern Germany. Procambarus clarkii is known from at least ten localities in this lake system and was introduced into LR and LB in the late 1990s or early 2000s (a detailed description of the study area is available in Chucholl, 2011).

\section{> TRAPPING AND MEASUREMENTS}

Crayfish were captured with $60 \mathrm{~cm}$ long, cylindrical minnow traps with $4 \mathrm{~mm}$ mesh and 2 entrances, that were baited with dry cat food. In LR, the traps were set approximately every $10 \mathrm{~m}$ along the shoreline at a distance from shore of between 1 and $4 \mathrm{~m}$ and a depth of between 0.2 and $3 \mathrm{~m}$. The number of traps used was 13, except in April, July and October 2007, when only 7, 8 and 5 traps were used, respectively. Traps were exposed for $16 \mathrm{~h}$ beginning at $8 \mathrm{pm}$ and one catch per unit effort (CPUE) corresponds to the catch of one trap set for $16 \mathrm{~h}$. The same trapping scheme was used in LB, however, traps were exposed between one day and two weeks as a result of low capture rates and ice cover in the winter. Surface water temperature, conductivity and $\mathrm{pH}$ were measured at both study lakes at a $1 \mathrm{~m}$ distance from shore on each sampling occasion (Conduktometer LF 191 WTW, pH 197-S WTW).

Upon capture, the carapace length (CL: measured from the tip of the rostrum to the dorsal posterior margin of the cephalothorax with a digital slide calliper) and sex were noted for each specimen. Mature male Cambarid crayfish show a cyclic dimorphism between a sexually active and a sexually inactive form. Sexually active males are referred to as being first form (I) and can be distinguished from sexually inactive males (form II) by having greatly inflated chelae, prominent copulatory hooks and cornified gonopodia (Huner and Barr, 1991; Huner, 2002). The reproductive form was noted for each captured male. Active glair glands, eggs, juveniles and egg-remains on female pleopods were also noted. The presence of those reproductive traits was interpreted as sexual maturity in females, whereas the form I condition was used to determine sexual maturity in males. To assess the relationship between $C L$ and body weight $(W), 261$ females and 52 form I males were weighed (Kern balance, type 822-67). After measurements, all males were returned to the lake and all females were transported to the laboratory. 


\section{$>$ GROWTH}

The obtained size frequency data were analysed in FiSAT 2 (v.1.2.2.; Gayanilo and Pauly, 1997; Ligas, 2008; Scalici et al., 2010). Growth was described using Von Bertalanffy's growth function (VBGF). Because of the pronounced seasonal changes in temperature, the "seasonalized" equation derived by Pauly and Morgan (1987) was used: $L(t)=L_{\infty}\{1-$ $\left.e^{[-k(t-t 0)-(C k / 2 \pi)(\sin 2 \pi(t-t s)-\sin 2 \pi(t 0 t s))]}\right\}$, where $L(t)$ is the $C L$ at age $t, L_{\infty}$ the asymptotic length (i.e., the theoretical possible $C L$ ), $k$ the curvature parameter (i.e., the rate at which $L_{\infty}$ is approached) and $t_{0}$ the initial condition parameter (i.e., the hypothesised age at which $C L$ is zero). $T_{s}$ refers to the onset of the first oscillation relative to $t=0$, but for practical purposes it was replaced by the winter point $\left(W P=t_{s}+0.5\right)$, i.e., the moment in which the growth rate is the slowest in the annual cycle. $C$ is a constant parameter expressing the amplitude of the seasonal growth oscillation.

$L_{\infty}$ and $k$ were estimated using the ELEFAN I procedures included in FiSAT 2 (non-parametric scoring; Pauly and David, 1981; Gayanilo and Pauly, 1997) and $t_{0}$ by non-linear regression analysis. Longevity $\left(t_{\max }\right)$ was estimated by $t_{\max }=(3 / k)+t_{0}$ and mean life-time by $t_{1 / 2}=\{\Sigma[n(t) t]\} / N$, where $n$ is the number of individuals at time $t$ and $N$ the total number of individuals (Gayanilo and Pauly, 1997; Scalici and Gherardi, 2007). The growth performance index $\left(\varnothing^{\prime}\right)$ was derived from $k$ and $L_{\infty}$ by applying the equation $\varnothing^{\prime}=\log (k)+2 \log \left(L_{\infty}\right)($ Pauly and Munro, 1984). $\varnothing^{\prime}$ allows to compare different stocks' growth performance in terms of length. Populations of the same species present similar values of $\varnothing^{\prime}$ and $\varnothing^{\prime}$ can therefore be used to identify biased growth parameter estimates (Pauly and Monroe, 1984). The total mortality index $(Z)$ was obtained in FiSAT2 from the Powell-Wetherall plot equation, which computed $L_{\infty}$ and the ratio $Z / k$ using length-frequency data. $Z$ is the sum of natural mortality $(M)$ and the mortality resulting from fishing $(F)$. M was obtained by solving the equation $\log (M)=-0.0066-0.279 \log \left(L_{\infty}\right)+0.6543 \log (k)-0.463 \log (T)$, where $T$ is the mean environmental temperature during the study period (Pauly, 1980). $F$ was calculated by subtracting $M$ from Z (Pauly, 1980).

\section{> FEMALE REPRODUCTIVE PATTERN}

The females captured from LR were transported to the laboratory, frozen to $-18^{\circ} \mathrm{C}$ and later dissected to calculate the gonadosomatic index (GSI = gonad weight / W*100). Additional female specimens were collected by hand from the shallow lake margin during the night in June and October 2007 and again in September 2008. Only sane females were used for the GSI calculation to avoid bias from the lower W of specimens with regenerated or missing chelae. Prior to weight measurement, female specimens were put on blotting paper and were gently shaken 10 times to remove adherent water drops. Dissected gonads were also gently shaken 10 times prior to weighing (Kern balance, type 822-67). In addition to the GSI, the colour of the dissected gonads was used to assess the ovary development stage by adopting the scheme provided by Dörr et al. (2006): white = ovary at rest, orange to brown = maturing ovary, dark brown to black = mature ovary.

Female reproductive traits were followed closely in LB during the fall and winter months of 2008 and during the spring of 2009. The relationship between the proportion of females with active glair glands and water temperature was assessed by a Pearson product moment correlation.

\section{$>$ FECUNDITY}

Fecundity data were collected from ten egg-bearing females captured from LB on September 25,2008 . Upon capture, females were carefully transported to the laboratory and frozen to $-18{ }^{\circ} \mathrm{C}$. Pleopodal eggs and those ones attached on the pleon were later stripped off with a forceps and counted. 


\section{> SIZE AT MATURITY}

The $C L$ at which $50 \%\left(C L_{50}\right)$ and $95 \%\left(C L_{95}\right)$ of individuals matured was assessed by a logistic regression analysis of the proportion of mature specimens in each size class (Beatty et al., 2005). The probability of maturity $(p)$ at each size class (CL) was given by $p(C L)=1 /\left\{1+\exp \left[-\ln (19)\left(C L-C L_{50}\right) /\left(C L_{95}-C L_{50}\right)\right]\right\}$. Estimates for the parameters $C L_{50}$ and $C L_{95}$ were derived by fitting the model to the data in SigmaStat 3.5.

\section{$>$ TRAP BIAS}

Trap data are often biased towards more competitive individuals, e.g., form I males and larger females (France et al., 1991; Dorn et al., 2005; Price and Welch, 2009). To assess this bias, trap data were compared with hand captures obtained by SCUBA divers, which are likely to be less biased (Somers and Stetchey, 1986; France et al., 1991). France et al. (1991) suggest a minimum SCUBA sample size of 200 specimens to gain a reasonable picture of a crayfish population.

Five traps were set along a transect across the western part of LR (every $30 \mathrm{~m}$, with a distance of $150 \mathrm{~m}$ between opposite lake shores) on October 1, 2007. The maximum depth was $4 \mathrm{~m}$, and the vegetation was composed of dense stands of Elodea nuttallii (Planchon) St. John and scattered patches of Chara spp. Traps were checked in the morning of the next day, and captured crayfish were not returned to the lake. Beginning at $7 \mathrm{pm}$, three pairs of SCUBA divers entered the lake and captured crayfish along three parallel transects (one transect was the same as that used for trapping, and the other two were laid out $20 \mathrm{~m}$ to the left and $20 \mathrm{~m}$ to the right of the original). Crayfish were collected by hand or with small hand nets. Additionally, two people searched the opposite sides of the shallow lake margin enclosed by the two outermost transects for crayfish. The SCUBA captures lasted for one hour.

\section{> POPULATION SIZE ESTIMATE}

The trappable population size was estimated for both study lakes in 2008. Crayfish that were to be returned to the lakes were marked by clipping the distal margin of one uropod. Only males were marked at $L R$, and the size of the trappable male population was estimated by the weighted mean model (Begon, 1979). At LB, the uropod clipped was alternated with every marking occasion, resulting in three distinct batch markings. Crayfish caught more than once were newly marked. The size of the trappable population was estimated by Bailey's triplecatch method (Henderson, 2003).

\section{> THE INFLUENCE OF LATITUDE ON LIFE-HISTORY PARAMETERS}

The obtained life-history parameters of the study population in LR were used with data reported in the literature to test for significant interactions between latitude and $k, t_{\max }$ and $L_{\infty}$, using Pearson product moment correlations. The latitude of all the studied populations was directly obtained from the literature or by GIS software (Quantum GIS v.1.6.0).

\section{> STATISTICAL ANALYSES}

Apart from the above-cited analyses, Pearson product moment correlations were used to assess the relationships between total, male and female CPUE and water temperature in LR. The relationship between $C L$ and $W$ was described using the power equation $y=a x^{b}$, with $y=W$ and $x=C L$. Parameters $a$ and $b$ were estimated by employing a linear regression after log transformation of the data. The size-frequencies of the crayfish captured from LR 
were pooled per sex and month and compared to the values of the previous month by nonparametric Mann-Whitney rank sum tests. The GSI values of the captured females from LR were also pooled per month and compared to the values of the previous month by nonparametric Mann-Whitney rank sum tests. The interaction between CL and GSI was assessed for each sampling occasion by a Pearson product moment correlation. The relation between $C L$ and fecundity was also assessed by a Pearson product moment correlation. The sex ratio of the SCUBA catch and the sex ratio of the trap catch were compared by a chi-square-test. The same test was used to compare the proportion of form I males and to test whether the sex ratio obtained by either method differs significantly from 1:1. The size-frequencies obtained from the SCUBA catch and the trap catch were compared per sex by parametric $t$-tests. All statistical analyses were performed with SigmaPlot 10.0 (with SigmaStat 3.5 Integration). The data were tested for normality prior to statistical testing for differences.

\section{RESULTS}

\section{$>$ TRAP BIAS}

The SCUBA divers captured 192 P. clarkii specimens. The sex ratio did not differ significantly from 1:1 (chi-square-test: $\chi^{2}=0.375, p=0.54$ ). In comparison to the SCUBA catch, the traps largely overestimated the proportion of males within the total catch (trap bias $=17 \%$; chi-square-test: $\chi^{2}=5.016, p=0.025$ ) and the proportion of form I males among the total male population (trap bias $=24 \%$; chi-square-test: $\chi^{2}=7.746, p=0.005$ ). The size frequency derived from the SCUBA catch was composed of significantly smaller male individuals than the size frequency of males derived from the trap catch ( $t$-test: $t_{142}=3.104, p=0.002$ ), but this was not the case for females ( $t$-test: $\left.t_{96}=1.278, p=0.204\right)$. The sex ratio of the trap catch was significantly unbalanced in favour of males (chi-square-test: $\chi^{2}=5.362, p=0.02$ ).

\section{> POPULATION SIZE ESTIMATE}

Out of the 524 marked males in LR, 26 were recaptured at least once, whereas 156 crayfish were marked in LB, of which 21 were recaptured at least once. The estimated trappable male population size in LR (6708, SE = 1343; weighed mean model of 7 trapping occasions) was larger than the trappable population size in LB, which was estimated at 1922 (SE = 610; triple-catch method).

\section{> POPULATION DYNAMICS}

A total of 1585 crayfish from LR and 436 crayfish from LB were trapped and measured during the study period. The largest captured female specimens measured 76.1 and $76.0 \mathrm{~mm}$ in $C L$ and the largest captured males measured 66.6 and $71.4 \mathrm{~mm}$ in $C L$, for LB and LR respectively. There was a significant positive relationship between $C L$ and $W$ in both sexes (for males and females; linear regression: $N=52, R^{2}=0.985, p<0.001$ and $N=261, R^{2}=0.929, p<0.001$, respectively; Figure 1).

The CPUE in LR was highest in August and October 2007 and in July 2008 (Table I). Male CPUE was consistently higher than female CPUE and reached its maximum in both years in August. Female CPUE increased in the summer but decreased in August. However, female CPUE increased again in October 2007 (no data for October 2008 because several traps were stolen). There was no significant relationship between total, male or female CPUE and surface water temperature (Pearson product moment correlation, $p=0.58,0.29$ and 0.28 , respectively; Table I). The mean CL of males increased in both years until July and declined distinctly in August (Table I, Figure 2). The mean CL of females followed the same pattern with the exception of the period from April to July, 2007, when there was no increase in mean CL. 


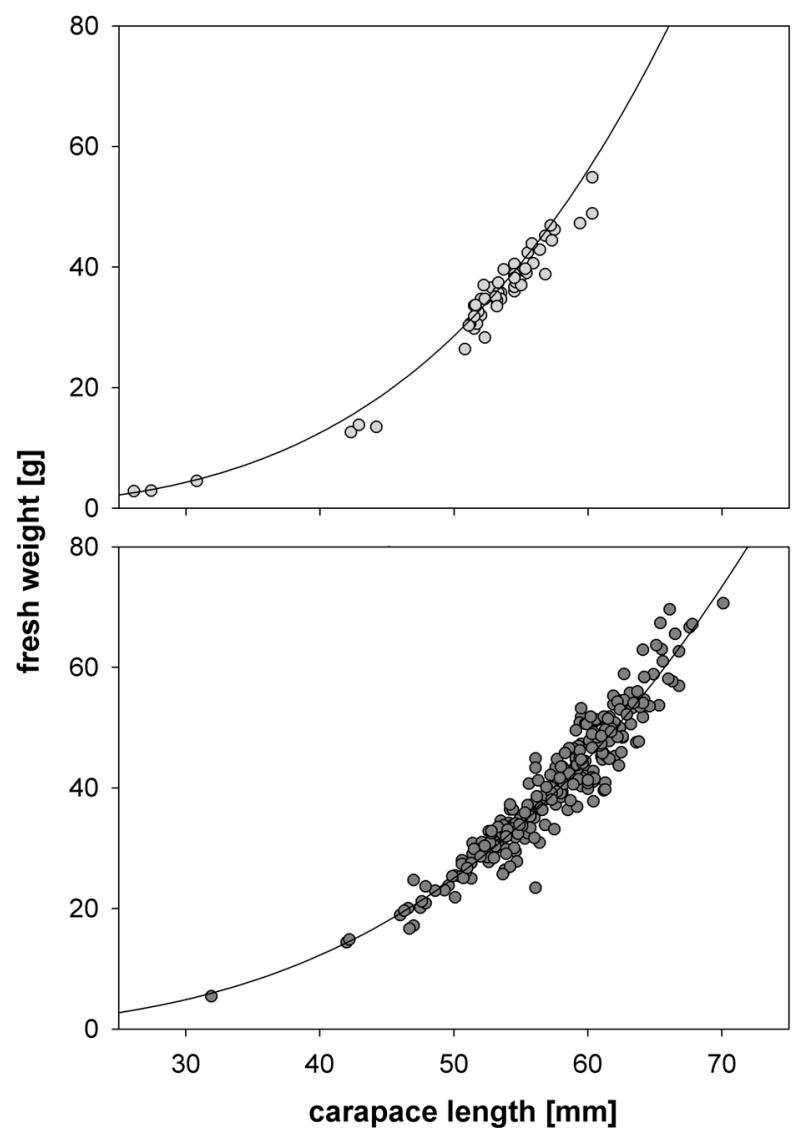

\section{Figure 1}

The length-weight relationship in male (light grey; form I in adults) and female (dark grey) P. clarkii from LR. Power equations were as follows: $W(g)=10^{-4.853} \mathrm{CL}(\mathrm{mm})^{3.703}$ in form I males and $W(g)=10^{-4.033}$ $C L(\mathrm{~mm})^{3.197}$ in females.

\section{Figure 1}

La relation taille-poids chez les mâles (gris clair) et femelles (gris foncé) de $P$. clarkii du lac Riedheim. Les équations sont : $W(\mathrm{~g})=10^{-4,853} \mathrm{CL}(\mathrm{mm})^{3,703}$ pour les mâles et $W(\mathrm{~g})=10^{-4,033} \mathrm{CL}(\mathrm{mm})^{3,197}$ pour les femelles.

Differences in the size-frequencies between months were assessed by Mann-Whitney rank sum tests and the results are summarized per sex in Table I. The proportion of form II males was generally low and was highest in the spring and autumn; form II males were virtually absent from the trap catches in the midsummer months (Table I).

\section{$>$ GROWTH}

Moulting individuals or shed exuviae were observed from May to late summer in both study years at surface water temperatures of greater than $15{ }^{\circ} \mathrm{C}$ - no moulting activities were detected below this temperature threshold. Because $P$. clarkii grows best at temperatures $>21^{\circ} \mathrm{C}$ (Huner, 2002), it is reasonable to assume that no growth occurred during the cold winter months. The WP of the seasonalized VBGF was therefore set to mid-winter, and C was set arbitrarily to 1, which allowed for no growth in winter (Gayanilo and Pauly, 1997). The resulting seasonal growth pattern and the size-frequencies of the study population in LR are shown in Figure 2 for each sex. The obtained Von Bertalanffy parameters $\left(L_{\infty}, k\right.$ and $\left.t_{0}\right)$, their derivates $\left(t_{\max }, \varnothing^{\prime}, Z, M\right.$ and $\left.F\right)$ and the calculated mean lifetime $\left(t_{1 / 2}\right)$ are summarised per sex in Table II. 


\section{Table I}

Procambarus clarkii population dynamics and surface water temperature (SWT) in LR. $f$ - females, $m$ males (form I and II pooled), $m$ I - form I males. Asterisks indicate significant differences in size-frequency from the previous month, given by a Mann-Whitney rank sum test $\left(^{*}=p<0.05,{ }^{* *}=p<0.01,{ }^{* *}=p<\right.$ 0.001).

Tableau I

la dynamique de la population de Procambarus clarkii et température des eaux de surface (SWT) dans le lac Riedheim. f - femelles, $\mathrm{m}$ - mâles (formes I et II en commun), m I - mâles forme I . Les astérisques indiquent des différences significatives dans la fréquence des tailles par rapport au mois précédent, données par un test de Mann-Whitney sur la somme des rangs $\left(^{*}=p<0,05,{ }^{* *}=p<0,01,{ }^{* * *}=p<\right.$ 0,001).

\begin{tabular}{|l|c|c|c|c|c|c|c|c|}
\hline & Mean $C L \mathrm{~m}$ & Mean $C L \mathrm{f}$ & $\mathrm{N}$ & $\mathrm{CPUE}$ & $\mathrm{CPUE} \mathrm{m}$ & $\mathrm{CPUE}$ & $\mathrm{\%} \mathrm{m} \mathrm{I} \cdot \mathrm{m}^{-1}$ & SWT $\left({ }^{\circ} \mathrm{C}\right)$ \\
\hline April 07 & 56.1 & 59.1 & 12 & 1.71 & 1.14 & 0.6 & 87.5 & 18.3 \\
\hline May 07 & 56.3 & 55.9 & 87 & 3.1 & 2.2 & 0.9 & 87.1 & 19.0 \\
\hline June 07 & 57.2 & 59.1 & 128 & 4.0 & 3.2 & 0.8 & 94.3 & 22.1 \\
\hline July 07 & 57.2 & 59.0 & 85 & 11.33 & 8.0 & 3.3 & 100.0 & 19.3 \\
\hline August 07 & $53.4^{* \star *}$ & $54.8^{\star *}$ & 146 & 12.2 & 10.8 & 1.5 & 100.0 & 23.9 \\
\hline October 07 & $55.1^{*}$ & 56.8 & 62 & 12.4 & 9.0 & 3.4 & 86.7 & 17.3 \\
\hline April 08 & 54.7 & 55.7 & 83 & 6.6 & 3.8 & 2.9 & 76.6 & 11.5 \\
\hline May 08 & 56.6 & 54.1 & 29 & 3.0 & 1.9 & 1.1 & 72.2 & 19.8 \\
\hline June 08 & 56.6 & 57.8 & 249 & 6.5 & 4.4 & 2.1 & 93.4 & 22.7 \\
\hline July 08 & 57.3 & 60.1 & 432 & 10.2 & 7.1 & 3.1 & 98.7 & 23.0 \\
\hline August 08 & $54.2^{* * *}$ & $56.7^{* * *}$ & 272 & 8.5 & 8.2 & 0.3 & 100.0 & 23.7 \\
\hline
\end{tabular}

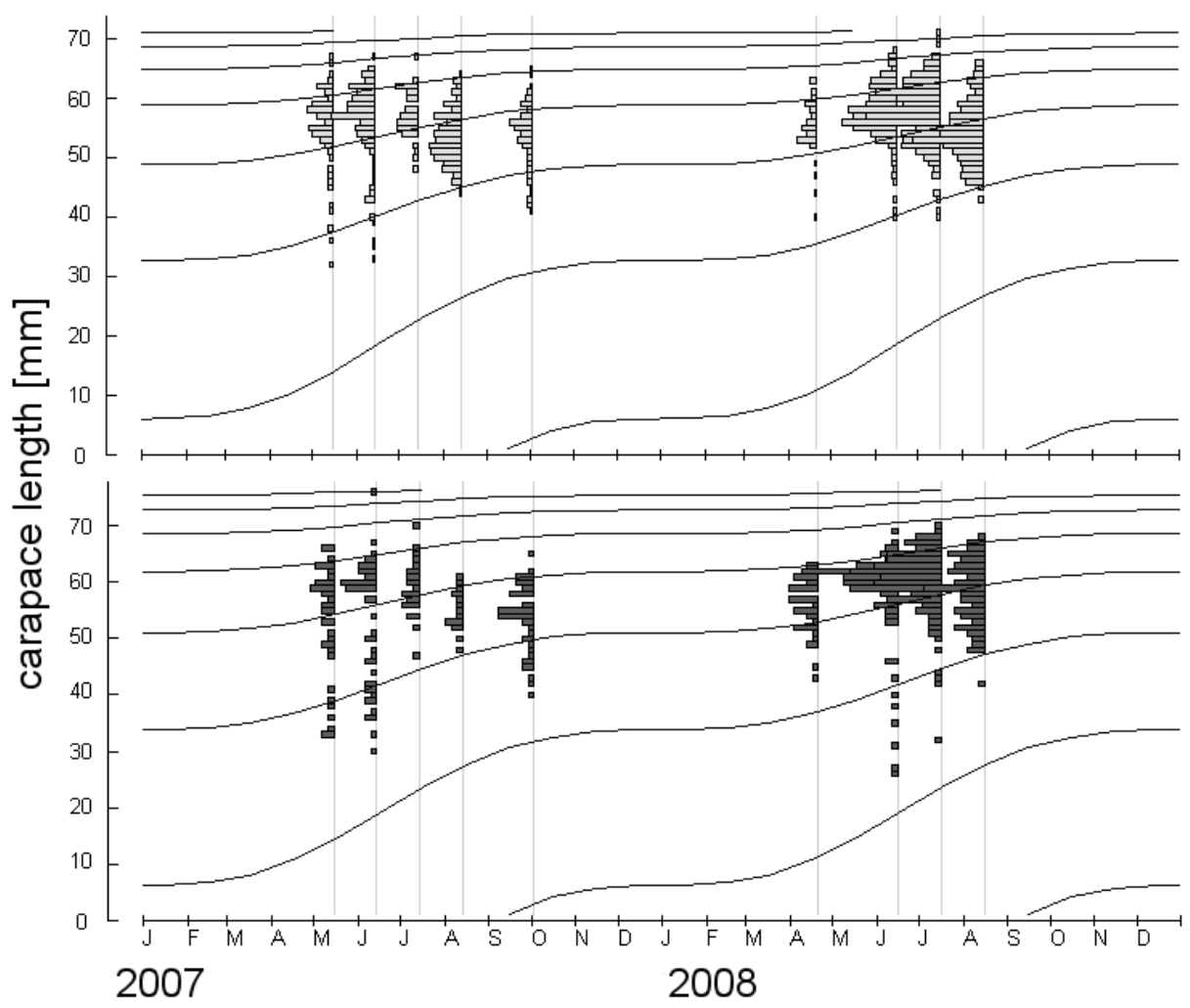

Figure 2

Growth models for Procambarus clarkii males (light grey) and females (dark grey) in LR, southern Germany.

\section{Figure 2}

Les modèles de croissance pour les mâles de Procambarus clarkii (gris clair) et les femelles (gris foncé) du lac Riedheim, sud de l'Allemagne. 


\section{Table II}

Von Bertalanffy's parameters (asymptotic $C L, L_{\infty}$, curvature parameter, $k$, and initial condition parameter, $\left.t_{0}\right)$, longevity $\left(t_{\max }\right)$, mean lifetime $\left(t_{1 / 2}\right)$, growth performance index $\left(\varnothing^{\prime}\right)$, total mortality index $(Z)$, natural mortality $(M)$ and mortality resulting from fishing $(F)$ of the P. clarkii population in LR, distinguished per sex.

\section{Tableau II}

Paramètres de Von Bertalanffy (longueur asymptotique de carapace, $L_{\infty}$, paramètre de courbure, $k$, et le paramètre de condition initiale, $\left.t_{0}\right)$, la longévité $\left(t_{\max }\right)$, la durée de vie moyenne $\left(t_{1 / 2}\right)$, l'indice de performances de croissance $\left(\varnothing^{\prime}\right)$, l'indice de la mortalité totale $(Z)$, la mortalité naturelle $(M)$ et la mortalité résultant de la pêche $(F)$ de la population de $P$. clarkii dans le lac Riedheim, par sexe.

\begin{tabular}{|l|c|c|c|c|c|c|c|c|c|}
\hline & $L_{\infty}$ & $k$ & $t_{0}$ & $t_{\max }$ & $t_{1 / 2}$ & $\sigma^{\prime}$ & $Z$ & $M$ & $F$ \\
\hline Males & 74.6 & 0.49 & -0.022 & 6.1 & 3.5 & 3.44 & 2.26 & 2.26 & 0.00 \\
\hline Females & 79.8 & 0.45 & -0.027 & 6.6 & 4.0 & 3.46 & 2.79 & 2.55 & 0.24 \\
\hline
\end{tabular}

\section{> FEMALE REPRODUCTIVE PATTERN}

The GSI of female crayfish in LR was consistently low in spring and increased until late summer in both years (Figure 3, Table III). The values differed significantly from those of the previous sample month in April and July, 2008 (Mann-Whitney rank sum test: $p<0.05$ ) and highly significantly in July and October, 2007, and June, 2008 (Mann-Whitney rank sum test: $p<0.001$; Table III).

In 2008, there were significant relationships between female CL and the GSI (Figure 4): on July 22, the relationship was significantly positive (Pearson product moment correlation: $N=$ 33 , corr. coeffic. $=0.44, p=0.01$ ), whereas it was significantly negative on September 11 , 2008 (Pearson product moment correlation: $N=14$, corr. coeffic. $=-0.57, p=0.04$ ). The relationship was not significant on the three intermediate capture occasions (August 6, 26 and 29, 2008; $p>0.05$; Figure 4).

Females with active glair glands were captured as early as June (2008) and accounted for up to $38 \%$ of the females captured in August (Figure 3, Table III). After August, the proportion of captured females with active glair glands decreased strongly in both years (Figure 3, Table III). A small proportion of the females captured in April 2008 also had active glair glands. Females with eggs or juveniles were found in October 2007, August 2008 and September 2008 (Figure 2). On April 16, 2008, one female with very few and apparently dead eggs was captured. Egg remains on the pleopods could be found in spring 2007 and 2008 as well as in October 2007 and September 2008 (Figure 3).

Female reproductive traits were followed closely in LB from autumn, 2008 to spring, 2009 on seven trapping occasions (Figure 5). In mid-September, $64 \%$ of the captured females had active glair glands, but the proportion dropped to $3 \%$ in late November. The proportion of females with active glair glands correlated significantly with water temperature (Pearson product moment correlation: $N=7$, corr. coeffic. $=0.97, p<0.001$; Figure 5). Egg-bearing females were most abundant on September 25 and still accounted for $13 \%$ of the captured females in late November, when water temperatures had fallen to well below $5{ }^{\circ} \mathrm{C}$. The first females with egg remains were noted on September 25, and their proportion accounted for $19 \%$ of the total in mid-November (Figure 5). The appearance of egg remains was notably linked to female size: on September 25, only females with a CL larger than $60 \mathrm{~mm}$ showed egg remains (18\%). It was not until mid-October that females with a $C L$ between 50 and $59 \mathrm{~mm}$ were found to carry egg remains (33\%). Females smaller $50 \mathrm{~mm}$ CL did not carry egg remains before mid-November (17\%).

\section{$>$ FECUNDITY}

The size of the sampled egg-bearing females ranged from 44.9 to $56.1 \mathrm{~mm} \mathrm{CL}$, and the mean $C L$ was $50.9 \mathrm{~mm}$. The number of pleopodal eggs averaged 285 per female (Figure 6). The 


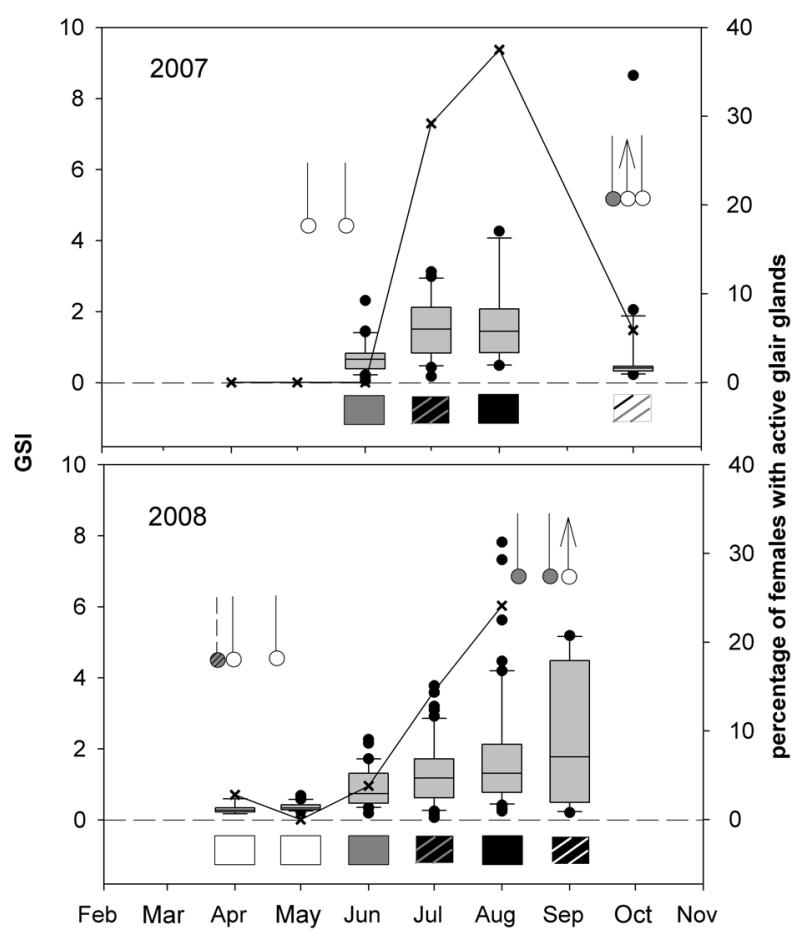

\section{Figure 3}

Reproductive traits of P. clarkii females in LR. The GSI is depicted with box plots (left axis; see Table III for statistics), and the frequency of females with active glair glands is depicted with a solid line (right axis). Boxes below the plots show the ovary development stages based on their colour: white - ovary at rest, dark grey - maturing ovary, black - mature ovary; hatched boxes indicate a mixture of ovary stages (dominant stage as background). Circle symbols depict females with eggs (solid grey), juveniles (open and upwards-pointing arrow) or egg remains (open); hatched symbol = single record with very few, dead eggs.

\section{Figure 3}

Traits de la reproduction des femelles de P. clarkii du lac Riedheim. Le GSI est représenté avec des boîtes en moustaches (axe de gauche; voir le tableau III pour les statistiques), et la fréquence des femelles ayant des glandes glaires actives est représentée par un trait plein (axe de droite). Les carrés en-dessous des graphiques représentent les étapes de développement des ovaires en fonction de leur couleur : blanc - ovaires au repos, gris foncé - maturation des ovaires, noir - maturité des ovaires; les boîtes hachurées indiquent un mélange de phases de l'ovaire (stade dominant comme arrière-plan). Les symboles représentent : femelles avec des œufs (cercle plein et gris), des juvéniles (cercle vide avec flèche vers le haut) ou restes d'œufs (cercle vide); symbole hachuré = enregistrement unique avec très peu d'œufs morts.

largest clutch (597 eggs) had a female with $51.8 \mathrm{~mm} \mathrm{CL}$, the smallest (7 eggs) a female with $44.9 \mathrm{~mm} C L$. There was no significant correlation between carapace length and the number of attached eggs (Pearson product moment correlation: $N=10$, corr. coeffic. $=0.31, p=0.39$; Figure 6). The highest number of eggs per pleopod was 105, and the mean egg count was 44 (pleopods without eggs excluded).

\section{> SIZE AT MATURITY}

The smallest captured form I male had a $C L$ of $37.1 \mathrm{~mm}$, the smallest female with active glair glands had a CL of $39.8 \mathrm{~mm}$ and the smallest gravid female had a $C L$ of $44.6 \mathrm{~mm}$. The $C L_{50}$ of male $P$. clarkii was estimated at $44.5 \mathrm{~mm}\left(S E=0.17\right.$; logistic regression analysis, $R^{2}=0.981$ ), and the $C L_{95}$ was estimated at $50.1 \mathrm{~mm}(S E=0.47$; Figure 7$)$. No estimates for $C L_{50}$ and $C L_{95}$ were derived for females as a result of a low sample size of the small size classes and 


\section{Table III}

Female reproductive traits in LR (cf. Figure 2). GSI stands for gonadosomatic index and SE for standard error. $N$ refers to the female sample size used for the GSI calculation (including trap captures and additional hand captures). Asterisks indicate significant differences from the previous month, given by a Mann-Whitney rank sum test $\left(^{*}=p<0.05 ;{ }^{* * *}=p<0.001\right)$.

\section{Tableau III}

Traits de reproduction des femelles dans le lac Riedheim (cf. Figure 2). GSI est l'indice gonadosomatique et SE l'erreur standard. N se réfère à la taille de l'échantillon femelle utilisé pour le calcul de GSI (comprenant les captures dans les pièges et les captures supplémentaires à la main). Les astérisques indiquent des différences significatives par rapport au mois précédent, données par un test de MannWhitney sur la somme des rangs $\left(^{*}=p<0,05 ;{ }^{* * *}=p<0,001\right)$.

\begin{tabular}{|l|c|c|c|c|c|}
\hline & $\begin{array}{c}\text { \% females w } \\
\text { glair glands }\end{array}$ & $\begin{array}{c}\text { \% females w } \\
\text { eggs/ juveniles }\end{array}$ & $\begin{array}{c}\text { \% females w } \\
\text { egg remains }\end{array}$ & Mean GSI (N) & SE GS/ \\
\hline April 07 & 0.0 & 0.0 & 0.0 & $\mathrm{x}$ & $\mathrm{x}$ \\
\hline May 07 & 0.0 & 0.0 & 12.0 & $\mathrm{x}$ & $\mathrm{x}$ \\
\hline June 07 & 0.0 & 0.0 & 9.1 & $0.76(27)$ & 0.08 \\
\hline July 07 & 29.2 & 0.0 & 0.0 & $1.54^{\star \star *}(24)$ & 0.17 \\
\hline August 07 & 37.5 & 0.0 & 0.0 & $1.72(16)$ & 0.28 \\
\hline October 07 & 5.9 & 5.9 & 0.0 & $0.89^{\star \star *}(21)$ & 0.40 \\
\hline April 08 & 2.8 & 2.8 & 11.1 & $0.31^{*}(9)$ & 0.04 \\
\hline May 08 & 0.0 & 0.0 & 27.3 & $0.38(23)$ & 0.03 \\
\hline June 08 & 3.8 & 0.0 & 0.0 & $0.89^{\star \star *}(34)$ & 0.09 \\
\hline July 08 & 14.5 & 0.0 & 0.8 & $1.322^{*}(58)$ & 0.12 \\
\hline August 08 & 24.1 & 0.0 & 0.0 & $1.82(53)$ & 0.22 \\
\hline September 08 & $\mathrm{x}$ & 0.0 & 14.3 & $2.3(14)$ & 0.53 \\
\hline
\end{tabular}

because of the seasonal influence on the presence of active glair glands and external eggs (i.e., it was often impossible to determine maturity in small females in the spring and summer; cf. Figure 2).

\section{> THE INFLUENCE OF LATITUDE ON LIFE-HISTORY PARAMETERS}

Longevity $\left(t_{\max }\right)$ and $L_{\infty}$ of $P$. clarkii populations correlated significantly positive with latitude (Pearson product moment correlation: $N=11$, corr. coeffic. $=0.85, p<0.001$ and $N=11$, corr. coeffic. $=0.76, p=0.006$, respectively), whereas $\mathrm{k}$ correlated significantly negative with latitude (Pearson product moment correlation: $N=11$, corr. coeffic. $=-0.79, p=0.004$; Figure 8).

\section{DISCUSSION}

The life-history analysis was based on a large number of captured crayfish and includes data from two consecutive years. Most data were obtained by baited traps, which can produce a bias in size and sex (France et al., 1991; Dorn et al., 2005) and are, therefore, a potential source of error. However, the comparison between trap and SCUBA data showed that the actual size bias was very small and, therefore, probably had no effect on the lifehistory analysis. The obtained growth performance indices are remarkably consistent with published values from Italian and Iberian populations (Anastácio and Marques, 1995; Chiesa et al., 2006; Scalici and Gherardi, 2007), indicating that the growth parameter estimates are unbiased (Pauly and Munro, 1984). The trappable population was probably composed of crayfish at least one-year-old, which becomes apparent from the growth model as shown in Figure 2, where smaller size classes (probably the $0+$ and $1+$ cohorts) are largely missing from the length frequency diagrams. As expected, the sex ratio of the trap data was considerably 

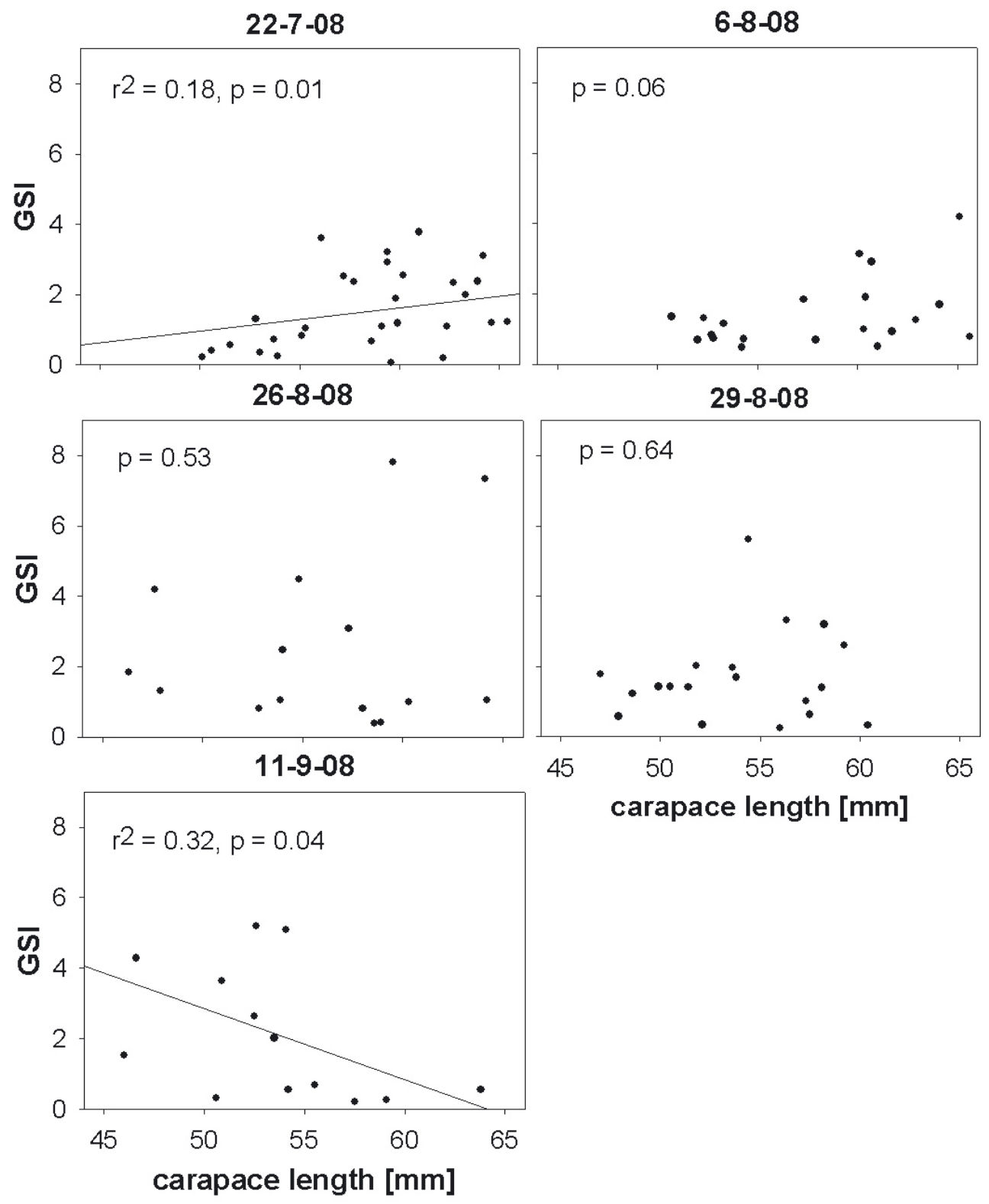

Figure 4

Relationship between female CL and the GSI in LR from late July to mid-September 2008. $P$ values are given by a Pearson correlation, and $r^{2}$ values were calculated by linear regression.

\section{Figure 4}

Relations entre la longueur de carapace CL des femelles et le GSI du lac Riedheim de fin juillet à la mi-septembre 2008. Les valeurs $P$ sont données pour une corrélation de Pearson, et les valeurs $r^{2}$ ont été calculées par régression linéaire.

biased towards males. The SCUBA data suggest a balanced sex ratio of the actual population as proposed by Gherardi et al. (1999) and Scalici and Gherardi (2007) for populations in central Italy. The natural mortality $(M)$ was lower than that of a $P$. clarkii population in central Italy (Scalici and Gherardi, 2007), which coincides with the suggestion of Frutiger et al. (1999) that $M$ is lower at higher latitudes. Fishing mortality $(F)$ was very low in females and not detectable in males, confirming that the study population was not subject to substantial fishing 


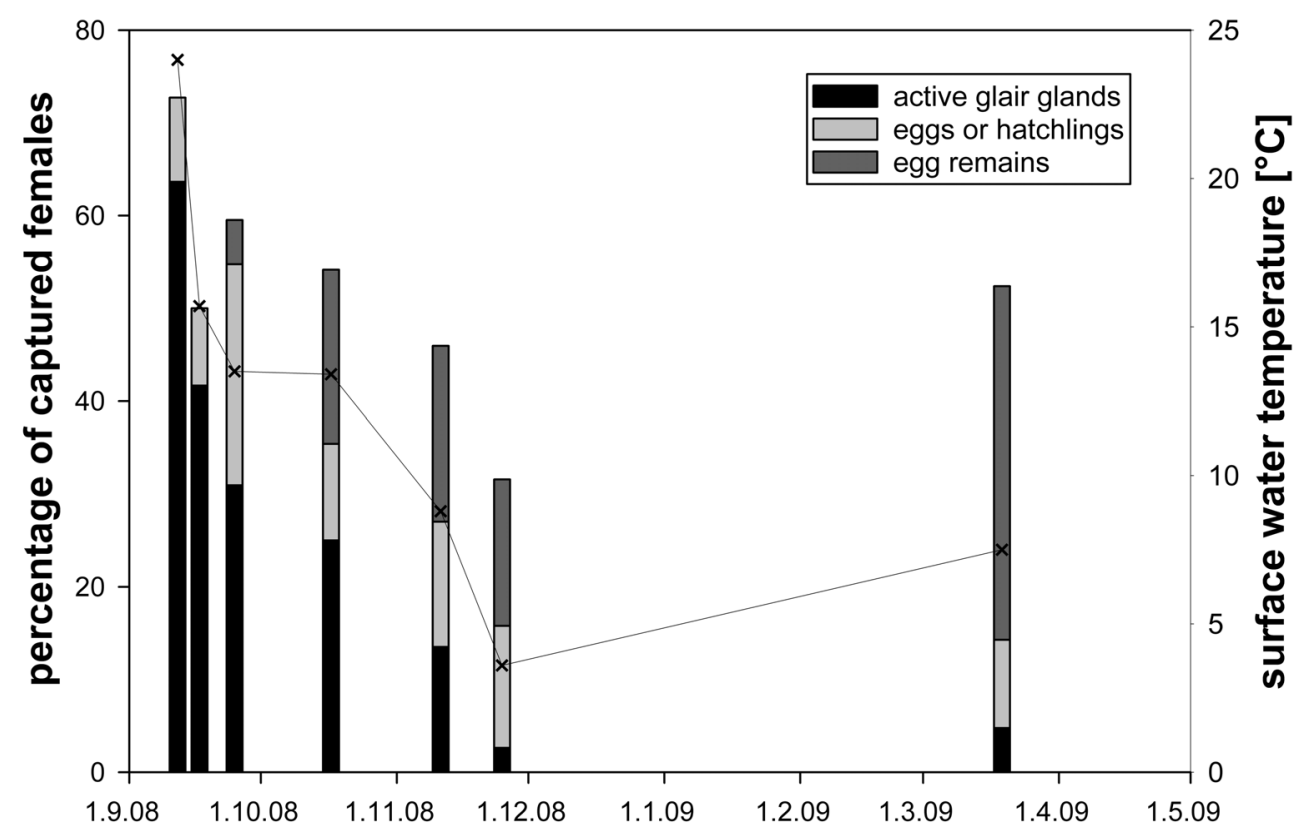

Figure 5

Female reproductive traits and surface water temperature (solid line; right axis) in LB from autumn, 2008 to spring, 2009.

\section{Figure 5}

Traits de reproduction des femelles et de température de l'eau de surface dans lac Riedheim de l'automne 2008 au printemps 2009.

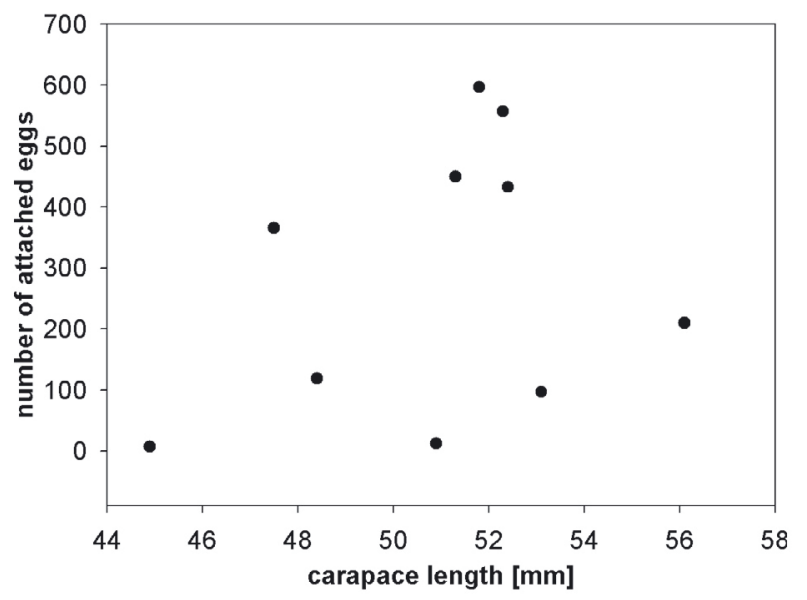

\section{Figure 6}

Fecundity of Procambarus clarkii females captured from LB in Summer 2008.

\section{Figure 6}

La fécondité des femelles de Procambarus clarkii capturées dans lac Riedheim pendant l'été 2008.

(cf. Chucholl, 2011). The selective removal of female crayfish from the lake for the calculation of the GSI during the present study probably contributed to $F$ in females.

\section{$>$ GROWTH}

The growth of crayfish is temperature dependant and decreases with temperature. Below a certain temperature threshold, it may cease completely (Reynolds, 2002). Huner and 


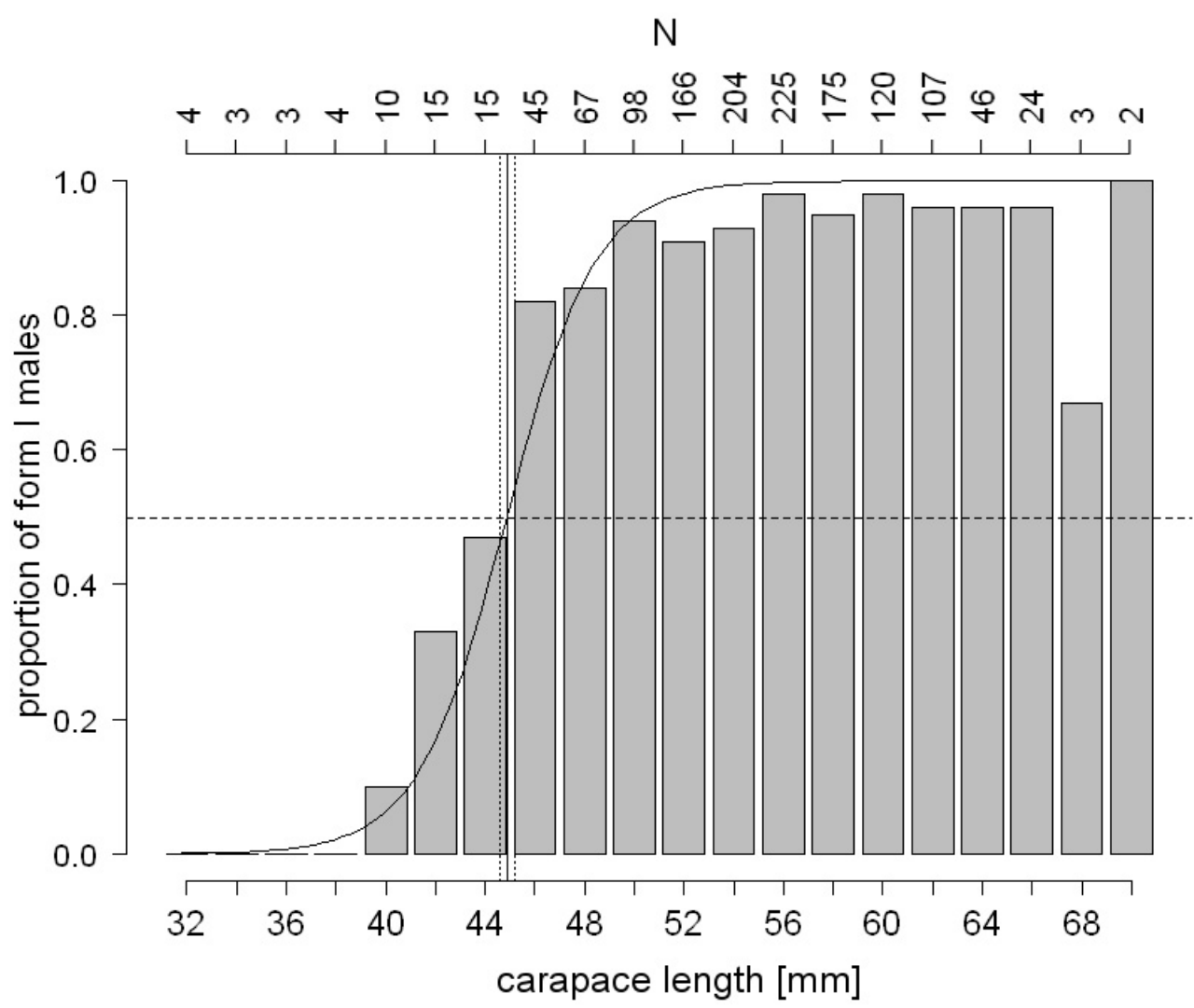

\section{Figure 7}

Size at maturity in male P. clarkii. Logistic curve was fitted to the proportion of form I males (regression analysis, $\left.R^{2}=0.981\right)$. The horizontal dashed line indicates a proportion of 0.5 . The vertical solid line depicts the estimated carapace length at which $50 \%$ of the males matured (SE as dotted lines). The sample size of each size class is given at the top of each column.

\section{Figure 7}

Taille à maturité des mâles de $P$. clarkii. La courbe logistique a été ajustée à la proportion de la forme I des mâles (analyse de régression, $R^{2}=0,981$ ). La ligne horizontale en pointillés indique une proportion de 0,5 . La ligne verticale pleine représente la longueur de la carapace estimée à laquelle $50 \%$ des mâles sont matures (SE en pointillés). La taille de l'échantillon de chaque classe de taille est indiquée en haut de chaque barre.

Barr (1991) stated that optimal growth of $P$. clarkii occurs at temperatures between 21 and $27{ }^{\circ} \mathrm{C}$. Surface water temperature in LR rarely exceeded $24^{\circ} \mathrm{C}$, and optimal growth conditions were reached only in the midsummer for three to four months. Low temperatures in the autumn, winter and spring restricted the growing season markedly and probably induced the comparatively slow growth rate (curvature parameter of the VBGF, $k=0.45$ and 0.49 ). Typical curvature parameters $(k)$ from populations in southern Europe are consistently higher and range between 0.62 and 0.85 (Anastácio and Marques, 1995; Chiesa et al., 2006; Dörr et al., 2006; Scalici and Gherardi, 2007). The slow growth was attended by a marked increase in longevity (up to 6.6. years), mean lifetime (3.5-4 years) and size. For comparison, longevity at lower latitudes was estimated to be 3.7 to 4.7 years (Huner, 2002; Chiesa et al., 2006; Scalici and Gherardi, 2007), and mean lifetime was estimated to be only 12 to 18 months (Huner, 2002; Scalici and Gheradi, 2007). The estimated asymptotic CL in southern Europe typically ranges between 56 and $66 \mathrm{~mm}$ (Anastácio and Marques, 1995; Chiesa et al., 2006; Scalici and Gherardi, 2007) as opposed to the $C L$ of 75 and $80 \mathrm{~mm}$ obtained by the present study. Increased mean lifetime, longevity and size were also reported from an introduced $P$. clarkii 

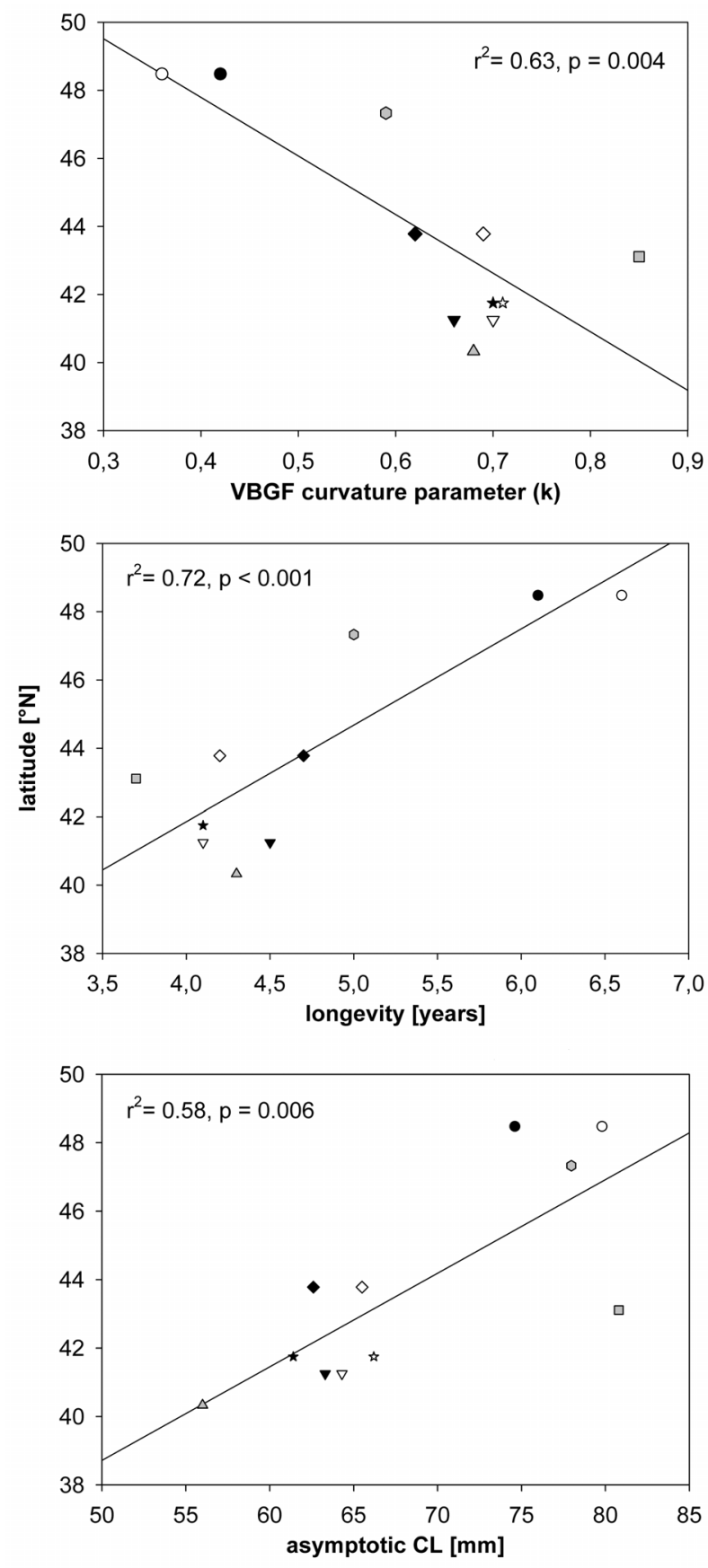

\section{Figure 8}

Life-history parameters of P. clarkii populations in Europe in relation to latitude. Symbol colour indicates the sex (white - female, black - male, grey - pooled) and symbol type depicts the data source (circle present study; hexagon - Frutiger et al., 1999; diamond - Scalici and Gherardi, 2007; rectangle - Dörr et al., 2006; asterisk - Chiesa et al., 2008; triangle down - Chiesa et al., 2006; triangle up - Anastácio and Marques, 1995). $P$ and $r^{2}$ values were calculated by linear regression.

\section{Figure 8}

Paramètres d'histoire de vie des populations de $P$. clarkii en Europe en fonction de la latitude. Le symbole de couleur indique le sexe (blanc - femelle, noir - mâle, gris - les deux sexes) la forme du symbole représente la source de données (cercle - cette étude; hexagone - Frutiger et al., 1999; losange Scalici et Gherardi, 2007; rectangle - Dörr et al., 2006 ; astérisque - Chiesa et al., 2008; triangle vers le bas - Chiesa et al., 2006; triangle vers le haut - Anastácio et Marques, 1995). $P$ et $R^{2}$ valeurs calculées par régression linéaire. 
population in Switzerland (Frutiger et al., 1999), which gives rise to the hypothesis that an increase in those life-history traits represents a general phenomenon at colder environments and, thus, a latitudinal cline. This idea is strongly supported by the fact that longevity, asymptotic $C L$ and curvature parameter ( $k$ ) were found to correlate with latitude (cf. Figure 8).

An increase in size at colder environments is known to occur in many ectotherms (Angilletta and Dunham, 2003), including latitudinal clines in aquatic macro-invertebrates, such as the freshwater pearl mussel (Margaritifera margaritifera (L., 1758); Bauer, 1992). Although this relationship between temperature and body size has been widely confirmed, a general explanation for this phenomenon has remained elusive (Atkinson and Sibly, 1997; Angilletta and Dunham, 2003; Stillwell, 2010). However, the increase in lifetime can be intuitively explained by the close relationship between growth rate and metabolism. At lower temperatures, metabolic rate declines and growth rate decreases (Reynolds, 2002). Consequently, more time is needed to attain the asymptotic length and longevity and mean lifetime increase (Bauer, 1992).

\section{$>$ REPRODUCTION}

Procambarus clarkii has a very plastic life cycle and is capable of surviving in tropical, subtropical and temperate climates worldwide. Data from its introduced tropical range (e.g., Costa Rica, Hawaii, Kenya and Uganda) suggest year-round breeding with at least two generations per year (Huner, 1977; Oluoch, 1990). Within its natural subtropical-temperate range (Louisiana, USA), P. clarkii also breeds year round, with distinct recruitment peaks from the late summer to early winter and again in the spring (Figure 9A). In populations in favourable conditions, there are up to three recruitment periods per year (Huner, 2002). In California, recruitment peaks in January and February, followed by smaller recruitment events in March, August and September (Sommer, 1984). In southern Spain, P. clarkii was shown to reproduce from April to late October, with ovigerous females found to be either continuously present from May to October (Gutiérrez-Yurrita et al., 1999) or peaking in September and May (Cano and Ocete, 1997). Introduced populations in Portugal may reproduce year round, with a single recruitment peak from October to November (Fidalgo et al., 2001) or several recruitment periods from mid-April to mid-June, in August and from October to mid-January (Figure 9D; Anastácio and Marques, 1995). In central Italy, populations exhibit breeding peaks in the spring and late summer/autumn (Figure 9C; Gherardi et al., 1999; Scalici and Gherardi, 2007). Similarly, naturalised $P$. clarkii populations in Japan show distinct reproduction peaks in MayJune and September-October, but egg-bearing females may be present in every season of the year, except in the deep winter (Suko, 1956, 1958).

In the present study, reproduction was shown to take place from the midsummer to late autumn, and the recruitment period lasted from autumn to winter. Single ovigerous females were also caught in the spring, but those females had most likely laid their eggs at the end of the previous autumn breeding period in late October and November (Figure 9B). Because egg development is effectively arrested at temperatures below $10^{\circ} \mathrm{C}$, it may take up to five months until those winter eggs hatch (Suko, 1956; Huner and Barr, 1991). The time of egg laying was notably related to female size, with larger females breeding earlier than smaller ones: GSI values were positively correlated with female size in late July, 2008 and were negatively correlated with female size in mid-September. This correlation suggests that the eggs of larger females matured earlier and that those larger females had already spawned by midSeptember (their GSI values were, therefore, lower than those of smaller individuals that had not yet laid their eggs). The presence of egg remains on female pleopods was also remarkably linked to female size and was first observed in larger females. A similar pattern was observed by Smith (1981) in Orconectes limosus (Rafinesque, 1817). Form I males peaked in the midsummer, and form II males were abundant only in the spring and autumn, which coincides with data from higher latitudes in North America (Pine Lake, Washington; Müller, 2007) but is diametrically opposed to the pattern at lower latitudes, where form II males peak in 


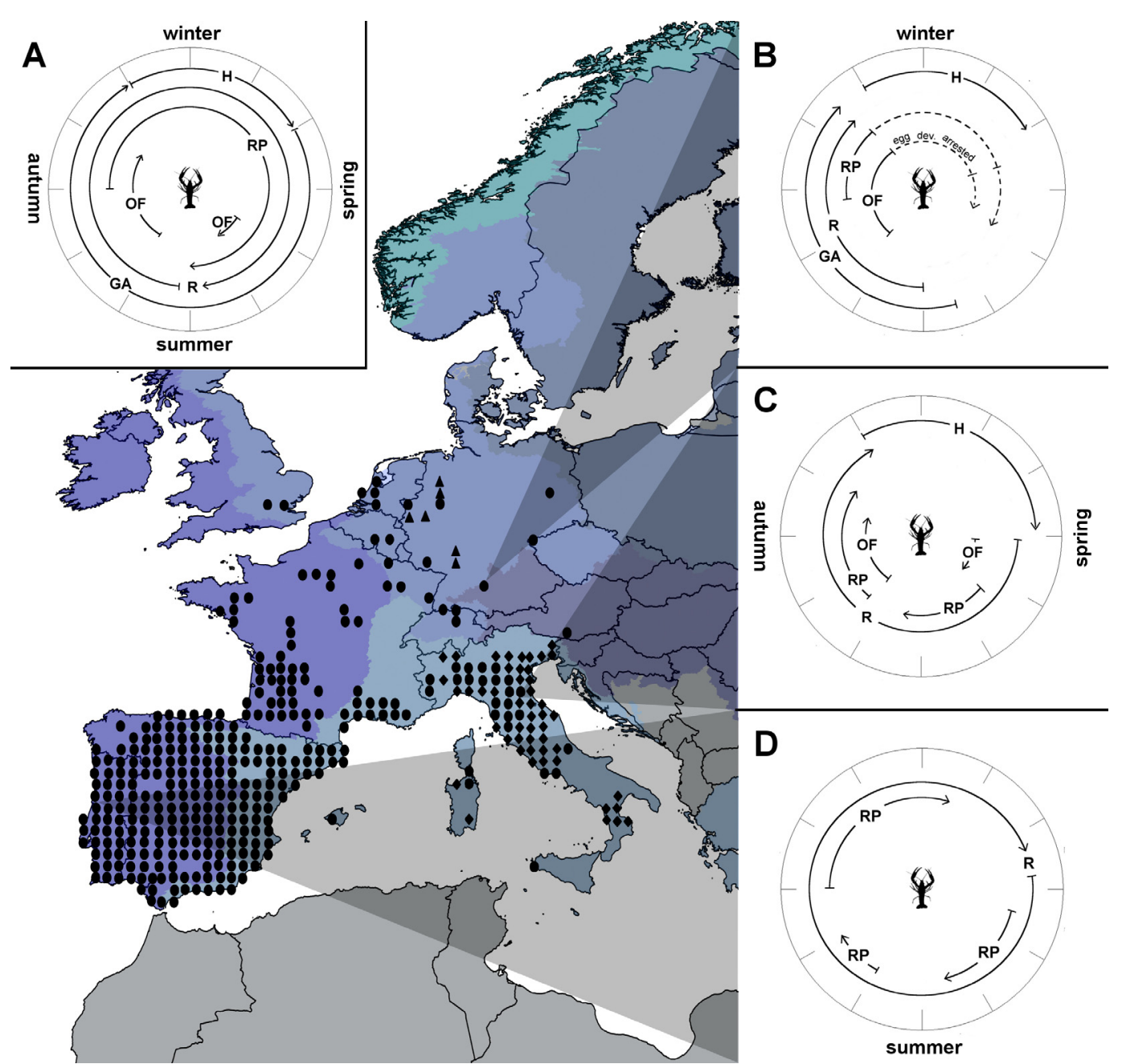

Figure 9

Life cycle of Procambarus clarkii in its native range $(A$, Huner, 2002) and across different latitudes of its introduced range in Europe (B: southern Germany, present study; C: central Italy, Gherardi et al., 1999; Scalici and Gherardi, 2007; D: Portugal, Anastácio and Marques, 1995). OF - ovigerous females, $G A$ - great activity, $R$ - reproduction, $R P$ - recruitment period, $H$ - hibernation. Distribution is shown as presence in CGRS squares (data source: dot - Souty-Grosset et al., 2006; diamond - Gherardi et al., 2009; triangle - Dümpelmann et al., 2009; Chucholl, 2011; Gross, 2011).

\section{Figure 9}

Cycle de vie de Procambarus clarkii dans son aire d'origine (A, Huner, 2002) et à travers différentes latitudes de son aire d'introduction en Europe (B : sud de l'Allemagne, la présente étude; C : I'Italie centrale, Gherardi et al., 1999; Scalici et Gherardi, 2007; D : Portugal, Anastácio et Marques, 1995). DE - femelles ovigères, GA - grande activité, $R$ - reproduction, RP - période de recrutement, $\mathrm{H}$ hibernation. La distribution est considérée comme étant la présence sur les carrés CGRS (source de données : points - Souty-Grosset et al., 2006; losange - Gherardi et al., 2009; triangle - Dümpelmann et al., 2009; Chucholl, 2011; Gross, 2011).

the summer and form I males are abundant in the spring, autumn and winter (Souty-Grosset et al., 2006).

When comparing the reproduction and recruitment patterns across different latitudes, two phenomena become apparent: first, there is a general trend from multi-voltine life cycles with year-round breeding (Figure 9A) at tropical climates to a univoltine life cycle with a seasonal recruitment pattern at higher latitudes (Figure 9B). Second, there is a latitudinal shift in the 
onset of the recruitment period in the annual cycle. At lower latitudes, the first recruitment wave usually starts in the spring months (Figures 9A, 9C, 9D), whereas at higher latitudes, recruitment does not occur before the late summer (Figure 9B).

Both phenomena, i.e., the switch from a multi-voltine to a univoltine life cycle and the seasonal shift in the timing of reproductive events, are most likely driven by the latitudinal gradient in water temperature. Ovarian development in $P$. clarkii is induced by increases in both photoperiod and temperature (Daniels et al., 1994), and eggs are rarely laid at temperatures below $15^{\circ} \mathrm{C}$ (Suko, 1958). At higher latitudes, most females are not able to attain breeding condition before midsummer, which is stressed by the consistently low GS/ values in the spring and by the positive correlation between the proportion of females with active glair glands and water temperature. Because egg development at optimal temperatures takes at least 2-3 weeks and because the egg maturation cycle takes at least six weeks (Huner and Barr, 1991), female $P$. clarkii can reproduce at most every two months. In colder environments, with low average temperatures during the winter half-year, this means that females can reproduce only once per year, from the late summer until the winter.

Contrary to the plastic recruitment pattern and timing of reproductive events, other reproduction-related life-history traits of $P$. clarkii seem to vary little across different latitudes. The estimated size at maturity for male $P$. clarkii and female fecundity data are comparable to values reported from permanent lake habitats in its natural and introduced ranges (Huner and Romaire, 1978; Olouch, 1990; Huner, 2002; Stucki, 2002).

Overall, $P$. clarkii adopted some $k$-selected life-history traits (slow growth, high longevity, large size), while retaining some of its typical r-selected characteristics (early maturation, high fecundity). Although the changes in the reproductive pattern most likely trace back to life cycle plasticity, it is unclear whether the large size can also be attributed to (phenotype) plasticity or whether it has a genetic basis and is adaptive (Stillwell, 2010). More studies are necessary to address this question and to confirm whether the observed life-history changes indeed represent latitudinal clines as proposed here.

The presented findings demonstrate that $P$. clarkii is able to cope well with a new cold habitat by modulating its life history and reproductive pattern. This is worrying, as new $P$. clarkii populations are increasingly discovered at temperate zones (Müller, 2007; Dümpelmann et al., 2009; Gross, 2011; cf. Figure 9). The prevention of any new introductions should therefore be of high priority.

\section{ACKNOWLEDGEMENTS}

I thank the local fishing associations for their kind permission to work at their lakes. I am also grateful to G. Maier, T. Stucki and M. Scalici for valuable information and P. Katzmann, M. Schlenker, W. Schüle and A. Vogeler for their assistance with fieldwork. The study was funded by the scholarship programme of the German Federal Environmental Foundation (DBU). The helpful comments of two reviewers are gratefully acknowledged.

\section{REFERENCES}

Anastácio P.M. and Marques J.C., 1995. Population biology and production of the red swamp crayfish Procambarus clarkii (Girard) in the lower Mondego river valley, Portugal. J. Crust. Biol., 15, $156-168$.

Angilletta Jr. M.J. and Dunham A.E., 2003. The temperature-size rule in ectotherms: simple evolutionary explanations may not be general. Am. Naturalist, 162, 332-342.

Atkinson D. and Sibly R.M., 1997. Why are organisms usually bigger in colder environments? Making sense of a life history puzzle. Trends Ecol. Evol., 12, 235-239.

Bauer G., 1992. Variation in the life span and size of the freshwater pearl mussel. J. Anim. Ecol., 61, 425-436. 
Beatty S., Morgan D. and Gill H., 2005. Role of life history strategy in the colonisation of Western Australian aquatic systems by the introduced crayfish Cherax destructor Clark, 1936. Hydrobiologia, 549, 219-237.

Begon M., 1979. Investigating animal abundance: capture-recapture for biologists, University Park Press, Baltimore, $97 \mathrm{p}$.

Cano E. and Ocete M.E., 1997. Population Biology of red swamp crayfish, Procambarus clarkii (Girard, 1852), in the Guadalquivir River marshes, Spain. Crustaceana, 70, 553-561.

Chiesa S., Scalici M. and Gibertini G., 2006. Occurrence of allochthonous freshwater crayfishes in Latium (Central Italy). Bull. Fr. Pêche. Piscic., 380-381, 883-902.

Chucholl C., 2011. Disjunct distribution pattern of Procambarus clarkii (Crustacea, Decapoda, Astacida, Cambaridae) in an artificial lake system in Southwestern Germany. Aquat. Invs., 6, DOI: 10.3391/ai.2011.6.1.

DAISIE European Invasive Alien Species Gateway, 2010. One hundred of the worst, available from: http://www.europe-aliens.org/speciesTheWorst.do [accessed 1st August 2010].

Daniels W.H., D'Abramo L.R. and Graves K.F., 1994. Ovarian development of female red swamp crayfish (Procambarus clarkii) as influenced by temperature and photoperiod. J. Crust. Biol., 14, 530-537.

Dehus P., Phillipson S., Bohl E., Oidtmann B., Keller M. and Lechleiter S., 1999. German conservation strategies for native crayfish species with regard to alien species. Custacean Issues, 11, 149-159.

Dorn N.J., Urgelles R. and Trexler J.C., 2005. Evaluating active and passive sampling methods to quantify crayfish density in a freshwater wetland. J. N. Am. Benthol. Soc., 24, 346-356.

Dörr A.J.M., La Porta G., Pedicillo G. and Lorenzoni M., 2006. Biology of Procambarus clarkii (Girard, 1852) in Lake Trasimeno. Bull. Fr. Pêche. Piscic., 380-381, 1155-1170.

Dümpelmann C., Bonacker F. and Häckl M., 2009. Erstnachweis des Rotem Amerikanischen Sumpfkrebses Procambarus clarkii (Decapoda: Cambaridae) in Hessen. Lauterbornia, 67, 39-47.

Fidalgo M.R.A., Carvalho P. and Santos P., 2001. Population dynamics of the red swamp crayfish, Procambarus clarkii (Girard, 1852) from the Averio Region, Portugal (Decapoda, Cambaridae). Crustaceana, 74, 69-375.

France R., Holmes J. and Lynch A., 1991. Use of Size-Frequency data to estimate the age composition of crayfish populations. Can. J. Fish. Aquat. Sci., 48, 2324-2332.

Frutiger A., Borner S., Büsser T., Eggen R., Müller R., Müller S. and Wasmer H.R., 1999. How to control unwanted populations of Procambarus clarkii in central Europe? Freshwater Crayfish, 12, 714-726.

Gayanilo Jr. FC. and Pauly D., 1997. The FAO ICLARM stock assessment tools, FiSAT reference manual, FAO Computerized Information Series (Fisheries), Rome, FAO.

Gherardi F., 2006. Crayfish invading Europe: the case study of Procambarus clarkii. Mar. Freshw. Behav. Physiol., 39, 175-191.

Gherardi F., Raddi A., Barbaresi S. and Salvi G., 1999. Life history patterns of the red swamp crayfish (Procambarus clarkii) in an irrigation ditch in Tuscany, Italy. Crustacean Issues, 12, 99-108.

Gherardi F., Aquiloni L., Tricarico E. and Morpurgo M., 2009. Süßwasserkrebse in Italien. In: Füreder L. (ed.), Flusskrebse: Biologie, Ökologie, Gefährdung, Folio, Wien/Bozen, 53-65.

Gross H., 2011. Edelkrebsprojekt NRW - Flusskrebsverbreitung, available from: http://www. edelkrebsprojektnrw.de/verbreitung_frame.htm [accessed January 12, 2011].

Gutiérrez-Yurrita P.J., Martínez J.M., Bravo-Utrera M.Á., Montes C., Ilhéu M. and Bernando J.M., 1999. The status of crayfish populations in Spain and Portugal. Crustacean Issues, 11, 161-192.

Henderson P.A., 2003. Practical Methods in Ecology, Blackwell Science, Oxford.

Henttonen P. and Huner J.V., 1999. The Introduction of alien species of crayfish in Europe: A historical introduction. Crustacean Issues, 11, 13-22.

Hobbs H.H., Jass J.P. and Huner J.V., 1989. A review of global crayfish introductions with particular emphasis on two North American species (Decapoda, Cambaridae). Crustaceana, 56, 299-316. 
Huner J.V., 1977. Introductions of the Lousiana red swamp crayfish, Procambarus clarkii (Girard); an update. Freshwater Crayfish, 3, 193-202.

Huner J.V., 2002. Procambarus. In: Holdich D.M. (ed.), Biology of Freshwater Crayfish, Blackwell Scientific Press, Oxford, 541-574.

Huner J.V. and Barr L.E., 1991. Red Swamp Crawfish: Biology, Culture, and Exploitation. Louisiana State University Sea Grant College System, Louisiana State University, Baton Rouge, Louisiana, 128 p.

Huner J.V. and Romaire R.P., 1978. Size at maturity as a means of comparing populations of Procambarus clarkii (Girard) (Crustacea, Decapoda) from different habitats. Freshwater Crayfish, 4, 53-64.

Ligas A., 2008. Population dynamics of Procambarus clarkii (Girard, 1852) (Decapoda, Astacidea, Cambaridae) from southern Tuscany (Italy). Crustaceana, 81, 601-609.

Lindqvist O.V. and Huner J.V., 1999. Life history characteristics of crayfish: What makes some of them good colonizers? Crustacean Issues, 11, 23-30.

Lodge D.M., Taylor C.A., Holdich D.M. and Skurdal J., 2000. Non indigenous crayfishes threaten North American Freshwater Biodiversity. Fisheries, 25, 7-19.

McGeoch M.A., Butchart S.H.M., Spear D., Marais E., Kleynhans E.J., Symes A., Chanson J. and Hoffmann M., 2010. Global indicators of biological invasion: species numbers, biodiversity impact and policy responses. Divers. Distrib., 16, 95-108.

Müller K.W., 2007. Reproductive Habits of Non-native Red Swamp Crayfish (Procambarus clarkii) at Pine Lake, Sammamish, Washington. Northwest Sci., 81, 246-250.

Nyström P., 1999. Ecological impact of introduced and native crayfish on freshwater communities: European perspectives. Crustacean Issues, 11, 63-85.

Nyström P., 2002. Ecology. In: Holdich D.M. (ed.), Biology of Freshwater Crayfish, Blackwell Scientific Press, Oxford, 192-224.

Oluoch A.O., 1990. Breeding biology of the Louisiana red swamp crayfish Procambarus clarkii Girard in Lake Naivasha, Kenya. Hydrobiologia, 208, 85-92.

Pauly D., 1980. On the interrelationships between natural mortality, growth parameters and mean environmental temperature in 175 fish stocks. J. Cons. CIEM. 39, 175-192.

Pauly D. and David N., 1981. ELEFAN I, a BASIC program for the objective extraction of growth parameters from length frequency data. Ber. Dtsch. Wiss. Kommission Meeresforschung, 28, 205-211.

Pauly D. and Morgan G.R., 1987. Length Based Methods in Fisheries Research, ICLARM, Manila, Filippines, and KIRSI, Safat, Kuwait, 468 p.

Pauly D. and Munro J.L., 1984. Once more on growth comparison in fish and invertebrates. Fishbyte, Newsletter Network Trop. Fish. Sci., 2, 21.

Price J.E. and Welch S.E., 2009. Semi-quantitative methods for crayfish sampling: sex, size, and habitat bias. J. Crust. Biol., 29, 208-216.

Reynolds J.D., 2002. Growth and Reproduction. In: Holdich D.M. (ed.), Biology of Freshwater Crayfish, Blackwell Scientific Press, Oxford, 152-191.

Rodríguez C.F., Bécares E., Fernández-Aláez M. and Fernández-Aláez C., 2005. Loss of diversity and degradation of wetlands as a result of introducing exotic crayfish. Biol. Invasions, 7, 75-85.

Sala O.E., Chapin III F.S., Armesto J.J., Berlow E., Bloomfield J., Dirzo R., Huber-Sannwald E., Huenneke L., Jackson R.B., Kinzig A., Leemanns R., Lodge D.M., Mooney H.A., Oesterheld M., Poff N.L., Sykes B.H., Walker B.H., Walker M. and Wall D.H., 2000. Biodiversity scenario for the year 2100. Science, 287, 1770-1774.

Scalici M. and Gherardi F., 2007. Structure and dynamics of an invasive population of the red swamp crayfish (Procambarus clarkii) in a Mediterranean wetland. Hydrobiologia, 583, 309-319.

Scalici M., Chiesa S., Scuderi S., Celauro D. and Gibertini G., 2010. Population structure and dynamics of Procambarus clarkii (Girard, 1852) in a Mediterranean brackish wetland (Central Italy). Biol. Invasions, 12, 1415-1425.

Smith D.G., 1981. Life History parameters of the crayfish Orconectes limosus (Raf.) in Southern New England. Ohio. J. Sci., 81, 169-172. 
Soes M. and van Eekelen R., 2006. Rivierkrefeten, een oprukkend problem? De Levede Natur, 107, $56-59$.

Somers K.M. and Stetchey D.P.M., 1986. Variable trappability of crayfish associated with bait type, water temperature and lunar phase. Am. Midl. Nat., 116, 36-44.

Sommer T., 1984. The biological response of the crayfish Procambarus clarkii to transplantation into California ricefields. Aquaculture, 41, 373-384.

Souty-Grosset C., Holdich D.M., Noel P.Y., Reynolds J.D. and Haffner P. (eds.), 2006. Atlas of Crayfish in Europe. Museum national d'Histoire naturelle, Paris, Patrimoines naturels, 64, $187 \mathrm{p}$.

Stillwell R.C., 2010. Are latitudinal clines in body size adaptive? Oikos, 119, 1387-1390.

Stucki T.P., 2002. Differences in life history of native and introduced crayfish species in Switzerland. Freshwater Crayfish, 13, 463-476.

Suko T., 1956. Studies on the development of the crayfish. IV. The development of winter eggs. Sci. Rep. Saitana Univ. (Jpn) Ser. B, 2, 213-219.

Suko T., 1958. Studies on the development of the crayfish. VI. The reproductive cycle. Sci. Rep. Saitana Univ. (Jpn) Ser. B, 3, 79-79. 